\title{
Up-estuary dispersal of young-of-the-year bay anchovy Anchoa mitchilli in the Chesapeake Bay: inferences from microprobe analysis of strontium in otoliths
}

\author{
Ryo Kimura ${ }^{1, *}$, David H. Secor ${ }^{2}$, Edward D. Houde ${ }^{2}$, Philip M. Piccoli ${ }^{3}$ \\ ${ }^{1}$ National Research Institute of Fisheries Science, Fukuura, Kanazawa, Yokohama, 236-8648, Japan \\ ${ }^{2}$ Chesapeake Biological Laboratory, University of Maryland Center for Environmental Science, PO Box 38, Solomons, \\ Maryland 20688-0038, USA \\ ${ }^{3}$ Department of Geology, University of Maryland, College Park, Maryland 20742, USA
}

\begin{abstract}
Young-of-the-year (YOY) bay anchovy Anchoa mitchilli occur in higher proportion relative to larvae in the upper Chesapeake Bay. This has led to the hypothesis that up-bay dispersal favors recruitment. Here we test whether recruitment of bay anchovy to different parts of the Chesapeake Bay results from differential dispersal rates. Electron microprobe analysis of otolith strontium was used to hind-cast patterns and rates of movement across salinity zones. Individual chronologies of strontium were constructed for 55 bay anchovy aged 43 to 103 d collected at 5 Chesapeake Bay mainstem sites representing upper, middle, and lower regions of the bay during September 1998. Most YOY anchovy were estimated to have originated in the lower bay. Those collected at 5 and 11 psu sites exhibited the highest past dispersal rates, all in an up-estuary direction. No significant net dispersal up- or down-estuary occurred for recruits captured at the polyhaline ( $\geq 18 \mathrm{psu})$ site. Initiation of ingress to lower salinity waters $(<15 \mathrm{psu})$ was estimated to occur near metamorphosis, during the early juvenile stage, at sizes $\geq 25 \mathrm{~mm}$ standard length (SL) and ages $\geq 50 \mathrm{~d}$ after hatch. Estimated maximum upstream dispersal rate (over-the-ground speed) during the first 50 to $100 \mathrm{~d}$ of life exceeded $50 \mathrm{~mm} \mathrm{~s}^{-1}$.
\end{abstract}

KEY WORDS: Sr:Ca $\cdot$ Otolith $\cdot$ Bay anchovy $\cdot$ Juvenile $\cdot$ Dispersal rate $\cdot$ Chesapeake Bay $\cdot$ Habitat

\section{INTRODUCTION}

Chesapeake Bay, the largest estuary in the United States, has a well-defined salinity gradient from its head to its mouth throughout the year. Oligohaline ( $\leq 6 \mathrm{psu}$ ) regions serve as important nursery habitats for several species of fish. Dovel (1971) hypothesized that migration or transport of larval and young-of-theyear (YOY) estuarine fishes to these 'critical zones'

*E-mail: rkim@nrifs.affrc.go.jp favored accumulation in these habitats and successful recruitment. Here we tested a part of this hypothesis by determining whether directed dispersals to oligohaline regions occur for bay anchovy Anchoa mitchilli larvae and YOY.

Bay anchovy is the most abundant fish in Chesapeake Bay (Hildebrand \& Schroeder 1928, Houde \& Zastrow 1991). It is a key forage species for several economically important fishes (Hartman \& Brandt 1995) and is an important consumer of zooplankton (Houde \& Zastrow 1991). Bay anchovy are euryhaline and occur throughout tidal estuaries and adjacent 
coastal regions from Cape Cod to the Yucatan. They spawn at salinities $>5$ psu, primarily from mid-May through mid-August (Zastrow et al. 1991). Although maximum spawning occurs typically at salinities $>15$ psu (Rilling \& Houde 1999a) in the lower twothirds of Chesapeake Bay, YOY recruits are in high abundance in samples collected in oligohaline waters (Dovel 1971). Spatial patterns in abundance of Chesapeake Bay anchovy eggs and subsequent distributions of larvae and juveniles suggest transport and/or migration from lower bay and offshore spawning areas to up-estuary nursery areas (Dovel 1971, MacGregor \& Houde 1996). Further, recent baywide sampling during fall months in Chesapeake Bay has shown distributions of YOY bay anchovy that are highly heterogenous. Jung \& Houde (http://www. chesapeake.org/ties/mwt/species/anc_yoy.htm, unpubl. data) observed that during the month of October in 1995-1998, YOY generally were in highest abundance in the mid-Bay region but were patchily distributed throughout Chesapeake Bay. If the primary spawning sites are in the lower and middle bay (Rilling \& Houde 1999a), then dispersal of most YOY may not occur beyond the mesohaline region, although many recruits are present in the oligohaline zone. While this behavior was postulated to be important to recruitment and was demonstrated to be consistent with observations on mortality and growth rates in the Patuxent River sub-estuary (Loos \& Perry 1991), there are no direct measures to confirm upestuary dispersal or dispersal rates during the larval or juvenile stages.

In this study, we applied electron microprobe analysis (EPMA) of otolith strontium to investigate estuarine dispersal patterns of larval and juvenile bay anchovy in Chesapeake Bay. For several estuarine fishes, otolith strontium is a useful tracer of ontogenetic and seasonal migrations (Secor \& Rooker 2000). Recent critical reviews by Campana (1999) and Thresher (1999) concluded that the otolith Sr:Ca ratio should relate positively to the ambient water $\mathrm{Sr}: \mathrm{Ca}$ ratio and salinity, particularly in estuaries showing large amplitude salinity gradients. Our goal was to determine whether the pattern of higher relative abundances of YOY in low-salinity regions of Chesapeake Bay resulted from directed dispersal. Alternatively, skewed size distributions could be the result of regional differences in past rates of growth and survival (McGregor \& Houde 1996). The objectives of this study were (1) to verify that otolith Sr levels were related to ambient salinity for YOY bay anchovy, (2) to test the hypothesis that YOY anchovies in the upper bay originated in lower bay regions, and (3) to estimate rates and ontogenetic patterns of bay anchovy dispersal.

\section{MATERIALS AND METHODS}

Fish collection. Samples were collected at 5 sites representing different salinity levels in the Chesapeake Bay mainstem during the week 7 to 14 September 1998 by the RV 'Cape Henlopen' (Univ. of Delaware). Salinity was determined from CTD casts. Sites had the following salinity ranges: $0-5,6-11,12-7$, 18-23, 24-29+ psu (Fig.1c, Table 1). Because we were unable to ascertain depth at which YOY were collected, we recorded site salinity as the mean of surface and bottom values.

YOY bay anchovy were collected in 20 min tows of an $18 \mathrm{~m}^{2}$ mouth-opening midwater trawl with $6 \mathrm{~mm}$ mesh liner in the codend. The net was towed obliquely in 2 min steps in depth bins from the surface to bottom. Sampled anchovy were sorted from catches and preserved immediately in $95 \%$ ethanol. For each site, 5 YOY anchovy from 2 size classes, 22 to 35 and 35 to $45 \mathrm{~mm}$, were chosen for analysis. At the 5 psu site, 5 additional YOY were examined ranging from 36.4 to $40.7 \mathrm{~mm}$ standard length (SL). To investigate the response of otolith $\mathrm{Sr}$ level to ambient salinity and to test whether larvae and juveniles show different responses, we analyzed additional samples of otoliths from 10 larvae (12 to $15 \mathrm{~mm} \mathrm{SL})$. These larvae were collected in waters of $10 \mathrm{psu}\left(39^{\circ} 00^{\prime} \mathrm{N}, 76^{\circ} 21^{\prime} \mathrm{W}\right), 20 \mathrm{psu}\left(37^{\circ} 30^{\prime} \mathrm{N}, 76^{\circ} 12^{\prime} \mathrm{W}\right)$, and $25 \mathrm{psu}\left(37^{\circ} 11^{\prime} \mathrm{N}, 76^{\circ} 03^{\prime} \mathrm{W}\right)$, using a Tucker trawl with $700 \mu \mathrm{m}$ mesh during July 1995 and 1997.

Otolith microprobe analysis. Sagittal otoliths extracted from fishes were embedded in Spurr epoxy, and sectioned in a sagittal plane with an ISOMET $^{\circ}$ saw, and mounted on a glass slide. Then otoliths were polished to the core with various grits of wet sandpaper (Secor et al. 1992). Final polishing was done using a piece of microcloth with 0.3 micron alumina oxide polishing compound to eliminate any surface structure which can cause artifacts in microprobe analysis (Gunn et al. 1992). Otolith concentrations of $\mathrm{Sr}$ and $\mathrm{Ca}$, which are estimated from their characteristic X-ray intensities, were quantified using a JEOL JXL-840A wavelength dispersive electron microprobe (Center for Microanalysis, University of Maryland, College Park) with calcite $\left(\mathrm{CaCO}_{3}\right)$ and strontianite $\left(\mathrm{SrCO}_{3}\right)$ as standards (Secor 1992). Strontium levels were expressed as $\mathrm{Sr}: \mathrm{Ca}$ ratios, using calcium as an internal standard. Calcium levels across otoliths are invariant relative to $\mathrm{Sr}$, and are used to reduce biases due to instrumental drift and error (Secor \& Rooker 2000). The concentrations at each probe point $\left(5 \times 5 \mu^{2}\right.$ area) on an otolith were measured at $25 \mathrm{kV}$ accelerating voltage and $20 \mathrm{nA}$ beam current. Background and peak counting times each were $50 \mathrm{~s}$ for $\mathrm{Sr}$ and $5 \mathrm{~s}$ for Ca. Analytical methods for measuring molar weights of $\mathrm{Sr}$ and Ca followed those described by Secor (1992). The minimum 

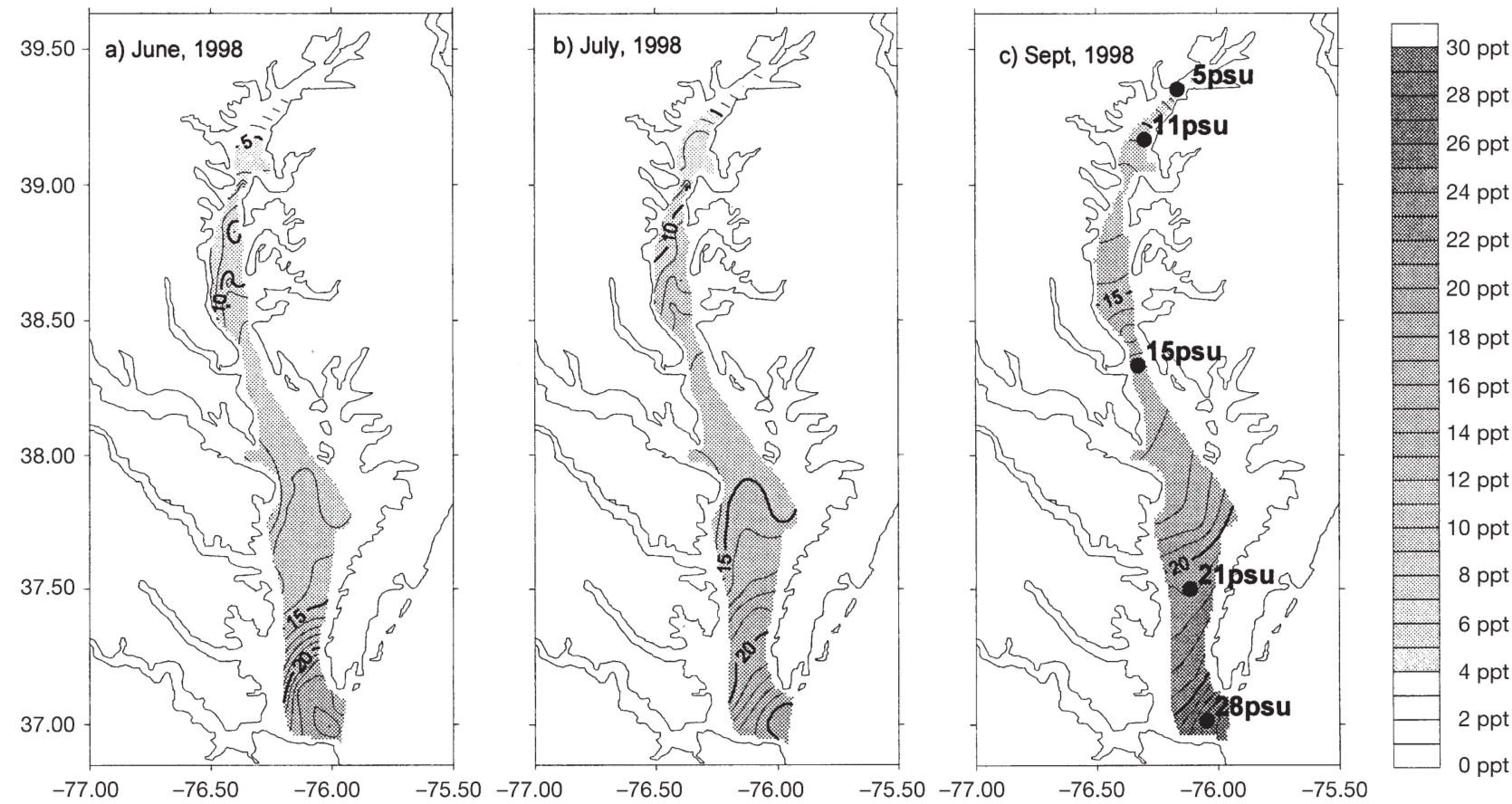

Fig. 1. Salinity isopleths (1 psu) for Chesapeake Bay in (a) June, (b) July, and (c) September 1998 over which the analyzed youngof-the-year (YOY) bay anchovy were spawned (June and July) and subsequently were collected (September)

detection limits for $\mathrm{Sr}$ and the $\mathrm{Sr}$ :Ca ratio in this analysis were $350 \mathrm{ppm}$ and $0.32 \times 10^{-3}$, respectively. In cases where $\mathrm{Sr}$ :Ca ratios were below this limit $(1.8 \%$ of 1025 probed points), we used the value $0.32 \times 10^{-3}$ in statistical analyses.

Two types of EPMA were performed: marginal point and transect analyses. Marginal analysis included 2 or 3 discrete point measurements taken near the edge of the otolith (the most recently formed part of the otolith), and was used to evaluate the relationship between otolith $\mathrm{Sr}: \mathrm{Ca}$ and ambient salinity. Transect analysis comprised a time series of point measurements beginning at the otolith core (the earliest formed part of the otolith representing embryonic and early larval stages) and ending at the peripheral edge of the postrostrum. Adjacent points in these chronologies were spaced at $30 \mu \mathrm{m}$ intervals. To minimize the unknown effect of instrument drift, we blocked samples in a slide by site so that an otolith from each site was measured in turn. Using light microscopy, distances from the core to each transect point, visible as faint marks on the carbon coating, were measured to the nearest $1 \mu \mathrm{m}$. For $27 \%$ of the samples, the analyzed transect did not precisely correspond to the desired core-postrostral axis. In these instances, the quotient of the core-postrostrum distance divided by the measured transect distance was used to standardize measurement of transect points from the core.

Otolith microstructure. Ages based upon otolith daily increments (Fives et al. 1986, Leak \& Houde 1987) were determined from randomly drawn subsamples of 15 YOY and 5 larvae. Five sagittal otoliths each were sub-sampled from 3 YOY size-bins (21-29, $29-37,37-45 \mathrm{~mm} \mathrm{SL}$ ) to ensure that ages were esti-

Table 1. Collection sites and samples of young-of-the-year (YOY) Chesapeake Bay bay anchovy used for EPMA analysis of otolith $\mathrm{Sr}:$ Ca. Collections were made during September 1998. Site indicates designated salinity (ca mean of surface and bottom salinity levels)

\begin{tabular}{|c|c|c|c|c|c|c|c|c|c|c|c|}
\hline \multirow[t]{2}{*}{ Site } & \multirow{2}{*}{$\begin{array}{l}\text { Salinity } \\
\text { (Region) }\end{array}$} & \multicolumn{2}{|c|}{ Location } & \multicolumn{3}{|c|}{ Salinity (psu) } & \multicolumn{2}{|c|}{ Temperature $\left({ }^{\circ} \mathrm{C}\right)$} & \multicolumn{3}{|c|}{ No. YOY analyzed } \\
\hline & & Lat. & Long. & Surface & Bottom & Mean & Surface & Bottom & Large & Small & Total \\
\hline $5 \mathrm{psu}$ & Oligohaline & $39^{\circ} 21^{\prime} \mathrm{N}$ & $76^{\circ} 10^{\prime} \mathrm{W}$ & 5.0 & 6.0 & 5.5 & 26.2 & 26.1 & 10 & 5 & 15 \\
\hline $11 \mathrm{psu}$ & Mesohaline & $39^{\circ} 10^{\prime} \mathrm{N}$ & $76^{\circ} 18^{\prime} \mathrm{W}$ & 9.9 & 11.8 & 10.9 & 25.8 & 25.8 & 5 & 5 & 10 \\
\hline $15 \mathrm{psu}$ & Mesohaline & $38^{\circ} 20^{\prime} \mathrm{N}$ & $76^{\circ} 20^{\prime} \mathrm{W}$ & 14.4 & 15.8 & 15.1 & 24.9 & 25.2 & 5 & 5 & 10 \\
\hline $21 \mathrm{psu}$ & Polyhaline & $37^{\circ} 30^{\prime} \mathrm{N}$ & $76^{\circ} 07^{\prime} \mathrm{W}$ & 19.6 & 21.4 & 20.5 & 24.1 & 24.8 & 5 & 5 & 10 \\
\hline $28 \mathrm{psu}$ & Polyhaline & $37^{\circ} 00^{\prime} \mathrm{N}$ & $76^{\circ} 03^{\prime} \mathrm{W}$ & 28.0 & 28.8 & 28.4 & 22.8 & 22.8 & 5 & 5 & 10 \\
\hline
\end{tabular}


mated for all length classes in the sample. Otolith daily increments were counted independently 3 times under a compound light microscope at $\times 150$ to $\times 300$ magnification. The coefficient of variation of daily increment counts was $5 \%$. The mean of the 3 increment counts plus $2 \mathrm{~d}$ was used to estimate age (Zastrow et al. 1991). Age at each probe measurement was estimated based upon a regression of age on otolith maximum radius (OR). The relationship between SL and OR, determined for all otoliths, was described by linear regression. This regression was used to estimate SL at each probe measurement point. High coefficients of determination $\left(\mathrm{r}^{2}\right)$ for these regressions (see 'Results') supported age prediction based upon radial increments.

Dispersal rate. Past dispersal rates of YOY were calculated based upon EPMA analysis and monthly bay monitoring data: (1) mean $\mathrm{Sr}: \mathrm{Ca}$ values were computed for each YOY corresponding to its first $20 \mathrm{~d}$ of life; (2) the mean Sr:Ca value was converted to salinity based upon a regression of ambient salinity on otolith $\mathrm{Sr}: \mathrm{Ca}_{i}(3)$ depth-averaged salinity contour maps of the Chesapeake Bay's mainstem (Fig. 1a,b) were constructed based upon monitoring data (Chesapeake Bay Program, Annapolis, MD, USA) for June (49 sites) and July (98 sites) 1998 using a kriging procedure (Surfer, Golden Software Inc., USA); (4) isohalines (1 psu) were plotted, and where these crossed the longitudinal midaxis of the bay mainstem, potential sites of origin were plotted to the nearest $0.1 \mathrm{psu}_{\text {; }}$ (5) YOY were assigned to sites according to either the June or July monthly salinity maps based upon YOY hatch dates; (6) dispersal distance was computed by summing mid-axis distances $(\mathrm{km})$ across isohalines separating site of origin (estimated using EPMA) and destination (collection site); and (7) dispersal distances were divided by predicted age to estimate dispersal rates. In cases where salinity at the site of origin was $>24$ psu in June and July, we could not confidently determine whether YOY originated from inside or outside the Chesapeake Bay. Spawning sites are typically concentrated in the midand lower-bay areas but can also occur outside the bay (Rilling \& Houde 1999a). In these instances ( $n=13)$, we designated the point of origin as the mouth of the bay $\left(37^{\circ} 00^{\prime} 42^{\prime \prime} \mathrm{N}, 75^{\circ} 59^{\prime} 18^{\prime \prime} \mathrm{W}\right)$.

The approach to estimate dispersal assumed the following: (1) unbiased and precise prediction of salinity at site of origin using EPMA ${ }_{i}(2)$ unbiased and precise prediction of age from otolith radius; and (3) accurate assignment of points of origin based upon monthly salinity maps. These assumptions and associated potential errors are addressed in the 'Discussion'.

Data analysis. Inferential statistics were used to address the following questions: (1) Are past dispersal rates related to site of collection? For example, do anchovy collected at oligohaline sites show greatest lifetime dispersal rates and distances? and (2) Are dispersal rates of larval and YOY-stage bay anchovy constant over their ontogeny? The first question was addressed based upon univariate analysis of variance (ANOVA) using the response variable $\mathrm{Sr}: \mathrm{Ca}_{\text {disp }}$, which is the difference between the mean $\mathrm{Sr}$ :Ca measured for the first $20 \mathrm{~d}$ of life and the mean $\mathrm{Sr}$ :Ca measured for the last 2 to $8 \mathrm{~d}$ of life (each phase measured by 3 probe points). Thus, $\mathrm{Sr}: \mathrm{Ca}_{\text {disp }}$ is an index of lifetime dispersal. Based upon the observed positive relationship between $\mathrm{Sr}: \mathrm{Ca}$ and ambient salinity, negative $\mathrm{Sr}: \mathrm{Ca}_{\text {disp }}$ values would indicate up-estuary dispersal. The effect of site of collection on this index of dispersal was tested. A significant effect of site of collection on lifetime dispersal would indicate that existing distribution patterns of YOY bay anchovies were influenced by past dispersal rates. Comparison of $\mathrm{Sr}: \mathrm{Ca}_{\text {disp }}$ means of YOY among collection sites was conducted with a Tukey post hoc test.

The second question, relating to ontogenetic patterns of dispersal, was evaluated using repeated measures ANOVA (Chambers \& Miller 1995, Fowler et al. 1995, Secor \& Piccoli 1996). Statistical procedures utilized mixed model analysis (SAS $8^{\odot}$ ). Each transect of probe points was divided into 5 age-stanzas, and mean $\mathrm{Sr}: \mathrm{Ca}$ values for stanzas were computed for 28 YOY that were each $>75$ d old. Age-stanzas were 15-29, $30-44,45-59,60-74$, and $75-89 \mathrm{~d}$. The means were expected to be autocorrelated. For instance, if a fish initiated an up-estuary dispersal at age $20 \mathrm{~d}$, it is probable that it would continue dispersing at a similar rate and direction at age $30 \mathrm{~d}$. Autocorrelation is typically modeled based upon compound symmetry in the covariance structure of repeated measures (Chambers \& Miller 1995). That is, given a dispersal rate at age $20 \mathrm{~d}$, the probability of a correlated dispersal rate at any subsequent age remains constant. This may be an unrealistically conservative expectation. We predicted that outcomes at age $20 \mathrm{~d}$ are less correlated (or more independent) with outcomes at progressively older ages. We tested this prediction by fitting an unstructured covariance matrix (Littell et al. 1996). The covariance matrix did show declining covariance (correlation) as observations became increasingly separated in time (Table 2). We use the unstructured covariance structure to test the following model

$$
\mathrm{Sr}: \mathrm{Ca}_{1 \ldots 5}=\text { Site }+ \text { Age-class }+ \text { Site } \times \text { Age-class }
$$

where $\mathrm{Sr}: \mathrm{Ca}_{1 \ldots 5}$ is the otolith transect time series of $\mathrm{Sr}$ :Ca values (Age-stanzas 1...5) for each chronology. The interaction term tested for ontogenetic differences in dispersal among collection sites. Post hoc contrasts were directed at the question: At which age-stanzas do up-estuary dispersals from polyhaline sites occur? 
Table 2. Unstructured covariance matrix for repeated lifehistory transect measures of $\mathrm{Sr}$ :Ca in Chesapeake Bay YOY bay anchovy. Values are sample covariances between age classes

\begin{tabular}{|llllll|}
\hline Age-class (d) & $15-29$ & $30-44$ & $45-59$ & $60-74$ & $75-89$ \\
\hline $15-29$ & 0.0632 & & & & \\
$30-44$ & 0.0502 & 0.0758 & & & \\
$45-59$ & 0.0263 & 0.0415 & 0.0648 & & \\
$60-74$ & 0.0173 & 0.0120 & 0.0265 & 0.0346 & \\
$75-89$ & 0.0128 & 0.0095 & 0.0092 & 0.0274 & 0.0332 \\
\hline
\end{tabular}

\section{RESULTS}

Mean SL (32.4 to $36.2 \mathrm{~mm}$ ) of YOY did not significantly differ among the 5 collection sites (ANOVA, $\mathrm{p}=0.8$ ). Estimated age of sampled larvae (sampled in July) and YOY (sampled in September) ranged from 15 to $101 \mathrm{~d}$ after hatch, and the mean age (69.7 to $75.7 \mathrm{~d}$ ) of YOY also did not differ among the 5 sites (ANOVA, $p>0.9)$. The daily growth rate, estimated from a linear model fit to size on age data $\left(\mathrm{r}^{2}=0.96\right)$, was $0.40 \mathrm{~mm} \mathrm{~d}^{-1}$ (Fig. 2a). Otolith radius was highly correlated with fish length $\left(\mathrm{r}^{2}=0.98\right.$; Fig. $\left.2 \mathrm{~b}\right)$ and age $\left(\mathrm{r}^{2}=0.97\right.$; Fig. $\left.2 \mathrm{c}\right)$.

Analysis of covariance (ANCOVA) detected no significant differences between larvae and YOY in the relationship: otolith marginal $\mathrm{Sr}$ :Ca versus ambient salinity $(p=0.9)$. No significant correlation was detected between otolith $\mathrm{Sr}$ :Ca and temperature $\left(\mathrm{r}^{2}=0.03\right)$. For combined life-history stages, marginal $\mathrm{Sr}$ :Ca was positively correlated with ambient salinity $\left(\mathrm{r}^{2}=0.54, \mathrm{p}<0.001\right.$; Fig. 3). Despite high variance in this relationship, there were significant differences in mean $\mathrm{Sr}: \mathrm{Ca}$ levels for YOY captured at sites with salinity $<15$ psu and those captured at sites $>15$ psu (ANOVA, p < 0.001). There was little overlap in Sr:Ca ratios between these groups. Highest variability in $\mathrm{Sr}$ :Ca levels was observed at $15 \mathrm{psu}$, which could not be distinguished from $\mathrm{Sr}: \mathrm{Ca}$ ratios at higher or lower salinity collection sites. The data supported a criterion level of $\mathrm{Sr}: \mathrm{Ca}=0.8 \times 10^{-3}$, which separated regions $<12$ psu from regions $\geq 18$ psu. Intermediate salinities (12 to $17 \mathrm{psu}$ ) could not be confidently distinguished from higher or lower salinity levels.

Larger size-class YOY fish from 21 and 28 psu collection sites showed levels of $\mathrm{Sr}: \mathrm{Ca}$ greater than $0.8 \times 10^{-3}$ (polyhaline habitat use) throughout their lives (Fig. $4 \mathrm{a}, \mathrm{b}$ ). For YOY collected at 5 to $15 \mathrm{psu}$, transect $\mathrm{Sr}$ :Ca values initially corresponded to polyhaline habitat use, but in most cases decreased to levels lower than $0.8 \times 10^{-3}$ at ages $>50 \mathrm{~d}$ after hatch, or $\geq 25 \mathrm{~mm} \mathrm{SL}$ (based upon regression shown in Fig. 2) (Fig. 4c-f). Smaller $(<35 \mathrm{~mm}$ SL) YOY showed the same trends (Fig. 5), but during the larval stage (points $<350 \mu \mathrm{m}$ from the core, ca $<25 \mathrm{~mm} \mathrm{SL}$ ), the mean $\mathrm{Sr}$ :Ca value differed slightly but significantly from that of large size-class YOY $\left(1.27 \times 10^{-3}, 1.13 \times 10^{-3}\right.$ respectively, $p=0.03$ ). Trends were otherwise similar between small and large size-class YOY: Sr:Ca ratios indicated mesohaline or polyhaline habitat use throughout life for those YOY collected at polyhaline sites; YOY collected at 5 and 11 psu sites exhibited $\mathrm{Sr}$ :Ca ratios that initially declined, indicating early polyhaline habitat use followed by gradual dispersal to oligohaline habitats.

Apparent up-bay dispersal rates differed according to collection site (Table 3). The rate was higher for the 5 and 11 psu sites than for the polyhaline sites. For YOY collected at the 5 psu site, maximum dispersal rate was estimated to be $5.6 \mathrm{~km} \mathrm{~d}^{-1}\left(65 \mathrm{~mm} \mathrm{~s}^{-1}\right)$ with a
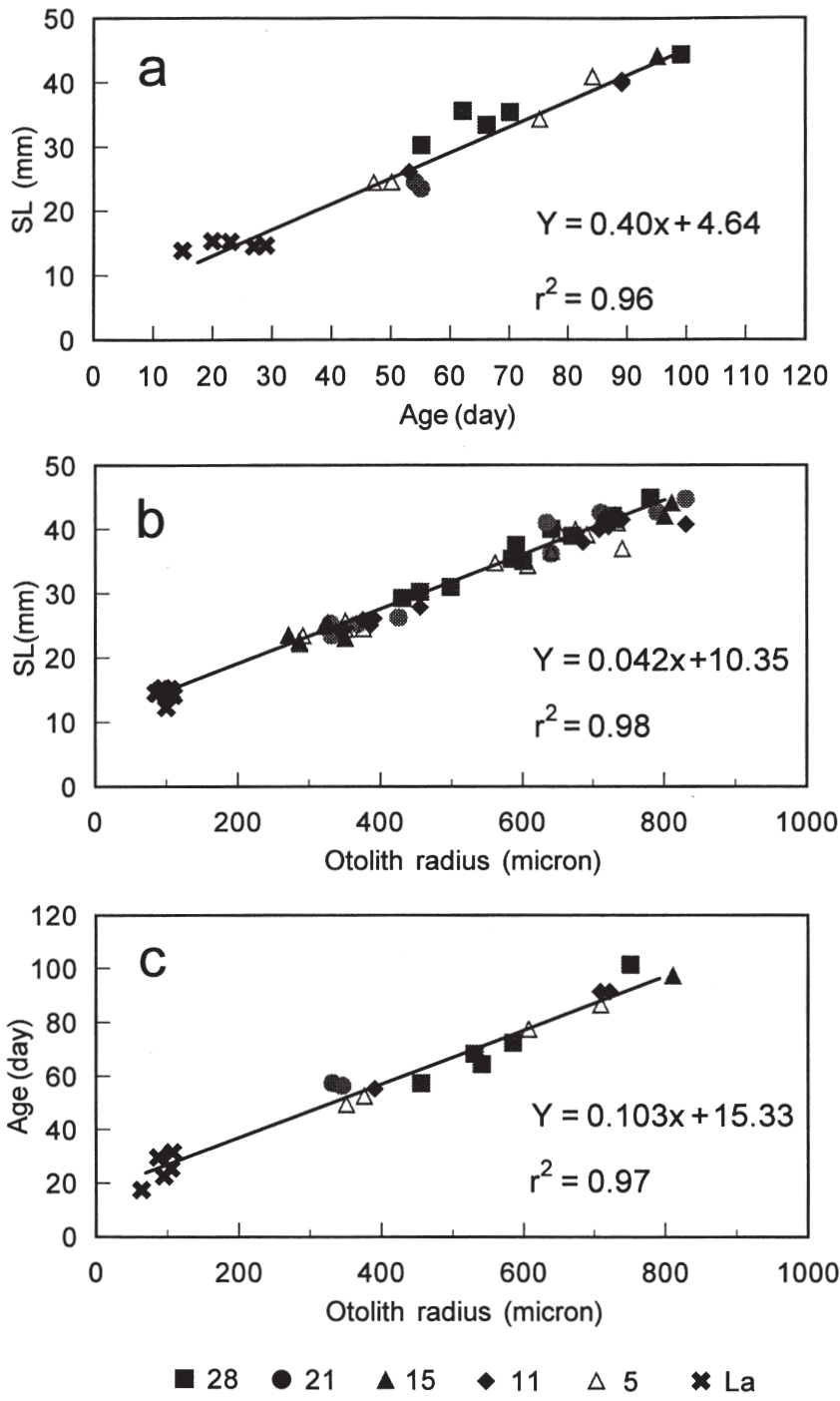

Fig. 2. Regressions of size (SL, mm) on (a) estimated age, (b) size on otolith radius, and (c) estimated age on otolith radius for larvae and YOY Chesapeake Bay bay anchovy collected in 1998. Different symbols correspond to site at YOY capture (with site salinity) and La indicates larvae 


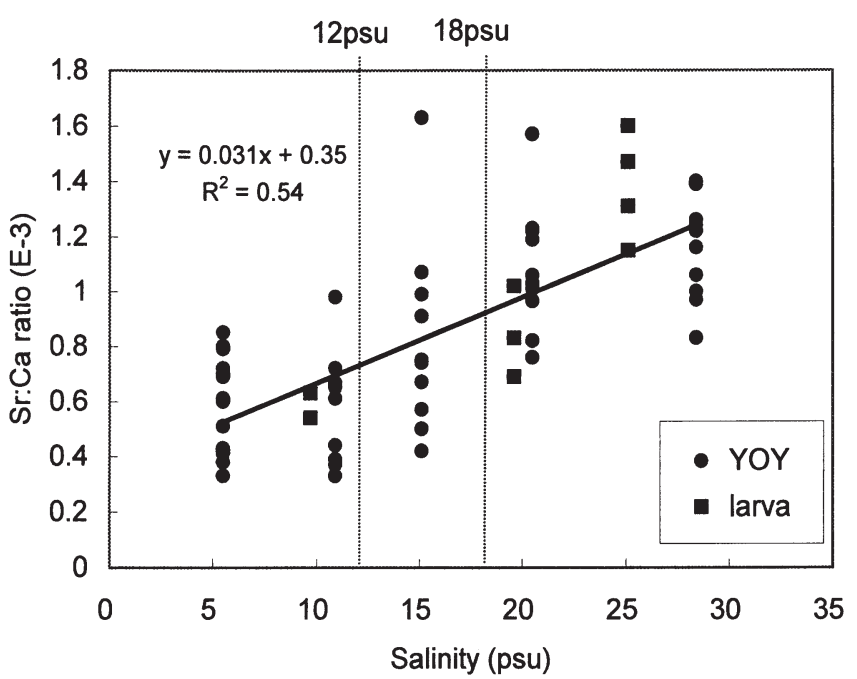

Fig. 3. Regression of marginal $\mathrm{Sr}$ :Ca on ambient salinity for combined larvae and YOY Chesapeake Bay bay anchovy collected 1995-1998

mean of $3.4 \mathrm{~km} \mathrm{~d}^{-1}$. Past dispersal rates were similar for YOY collected at $11 \mathrm{psu}$. At $15 \mathrm{psu}$, maximum rate was $3.4 \mathrm{~km} \mathrm{~d}^{-1}$ and at polyhaline collection sites, rates ranged from 0.4 to $0.8 \mathrm{~km} \mathrm{~d}^{-1}$, and offered little evidence of directional dispersal. Lifetime differences in $\mathrm{Sr}: \mathrm{Ca}\left(\mathrm{Sr}: \mathrm{Ca}_{\mathrm{disp}}\right)$ were significantly affected by site of collection (ANOVA, p = 0.005). Age of YOY at collection varied (41 to $101 \mathrm{~d}$ after hatch) and had a small but significant effect on $\mathrm{Sr}: \mathrm{Ca}_{\text {disp }}$ (ANCOVA, $\mathrm{p}=0.01$ ). Multiple comparisons of means indicate that YOY collected at 5, 11, and 15 psu sites had significantly higher lifetime dispersal rates than those collected at $28 \mathrm{psu}$ (Fig. 6b). All other pair-wise comparisons were nonsignificant. For YOY collected at the 3 most up-estuary sites, past dispersal rates were statistically similar ( $p>0.3$; Table 3 ). Site of collection did not significantly influence Sr:Ca measurements near the otolith core (Fig. 6a), suggesting that all larvae originated from a similar range of salinity, i.e. $>15$ psu.

Table 3. Up-bay dispersal rates $\left(\mathrm{mm} \mathrm{s}^{-1}\right)$ predicted for Chesapeake Bay YOY bay anchovy based upon life-history transect measures of $\mathrm{Sr}: \mathrm{Ca}$

\begin{tabular}{|lccc|}
\hline Site & Mean $\pm \mathrm{SD}$ & Maximum & Minimum \\
\hline $5 \mathrm{psu}$ & $39.9 \pm 15.7$ & 64.9 & 13.7 \\
$11 \mathrm{psu}$ & $39.5 \pm 13.7$ & 59.1 & 25.5 \\
$15 \mathrm{psu}$ & $26.2 \pm 12.0$ & 39.2 & 4.2 \\
$21 \mathrm{psu}$ & $8.8 \pm 3.6$ & 13.8 & 3.1 \\
$28 \mathrm{psu}$ & $4.1 \pm 1.9$ & 6.2 & 0.9 \\
\hline
\end{tabular}

\section{Ontogenetic trends}

Ontogenetic trends in repeated measures of $\mathrm{Sr}: \mathrm{Ca}$ were significant and differed according to collection sites (Table 4). Because previous observations and analysis indicated that $\mathrm{Sr}$ :Ca values early in life did not differ among destination sites, we compared age-specific Sr:Ca between YOY anchovy collected at the combined polyhaline sites (21 to $28 \mathrm{psu}$ ) with those collected at 5,11, and $15 \mathrm{psu}$. The goal of these tests was to determine the age at which up-estuary dispersals were initiated. For age-stanzas 15 to 29 and 30 to $44 \mathrm{~d}$ after hatch, there were no significant differences among sites ( $p>0.1)$. Sr:Ca levels for YOY collected at 5 and 11 psu departed significantly from levels of the polyhaline group at age-class 45 to $59 \mathrm{~d}(\mathrm{p}<0.05)$. These differences were maintained for older age-classes. Differences in Sr:Ca levels for YOY collected at 15 psu were significant initially at age-stanza 60 to $74 \mathrm{~d}(\mathrm{p}<0.04)$ and this difference was maintained for the 75 to $89 \mathrm{~d}$ age-class. These general trends were observed in transect plots. YOY destined for dispersal to oligohaline regions showed initial declines in $\mathrm{Sr}: \mathrm{Ca}$ below the $0.8 \times 10^{-3}$ criterion at ca 40 to $60 \mathrm{~d}$ after hatch (Figs. $4 \& 5$ ).

\section{DISCUSSION}

Ontogenetic patterns in Sr:Ca in otoliths and ANOVAs in Sr:Ca vectors provided evidence for past up-estuary dispersal by Chesapeake Bay YOY bay anchovy collected at 5 and 11 psu sites. Sr:Ca ratios during the first $20 \mathrm{~d}$ of life did not differ among destination sites and were $>0.8 \times 10^{-3}$, suggesting that most YOY anchovy in 1998 had originated from either polyhaline or mesohaline spawning sites. This result is in agreement with Rilling \& Houde (1999a), who observed that in 1993 eggs and larvae were most abundant in the middle and lower Chesapeake Bay. After the larval stage, otolith Sr:Ca transects showed that some, but not all, YOY dis-

Table 4. Test of effects of age-class and site on repeated measures of Sr:Ca in Chesapeake Bay YOY bay anchovy. Degrees of freedom (df) were estimated using the Satterthwaite formula based upon an unstructured covariance matrix (Littell et al. 1996)

\begin{tabular}{|lccccc|}
\hline Source & \multicolumn{3}{c}{$\mathrm{df}$} & $F$ & $\mathrm{p}$ \\
\cline { 2 - 5 } & Numerator & Denominator & & \\
\hline Site & 4 & 47.8 & 7.4 & $<0.001$ \\
Age-class & 4 & 34.6 & 33.1 & $<0.001$ \\
Site $\times$ Age-class & 16 & 34.3 & 3.6 & $<0.001$ \\
\hline
\end{tabular}


persed to oligohaline regions. Thus, our results support the hypothesis of size- or age-specific directed dispersal by early-stage bay anchovy. But, in contrast to previous studies which proposed that up-estuary displacements occurred during the larval stage (Dovel 1971, Loos \& Perry 1991, MacGregor \& Houde 1996), we observed up-estuary dispersal only during the early juvenile, or possibly late-larval, stage (ca $>50 \mathrm{~d}$ ).

Results of EPMA depend upon the assumption that $\mathrm{Sr}: \mathrm{Ca}$ is a scalar of salinity (Secor \& Rooker 2000).
Campana (1999) generalized that 3 main factors affect Sr:Ca ratio in otoliths: environmental availability (i.e. salinity), growth rate, and temperature. For bay anchovy, we presented a regression of marginal otolith Sr:Ca on ambient salinity to support this assumption. In a literature meta-analysis, Secor \& Rooker (2000) reported that estuarine taxa showed intermediate otolith Sr:Ca levels to marine and freshwater taxa, in accordance with an expected relationship between ambient strontium and salinity. Experimental evidence
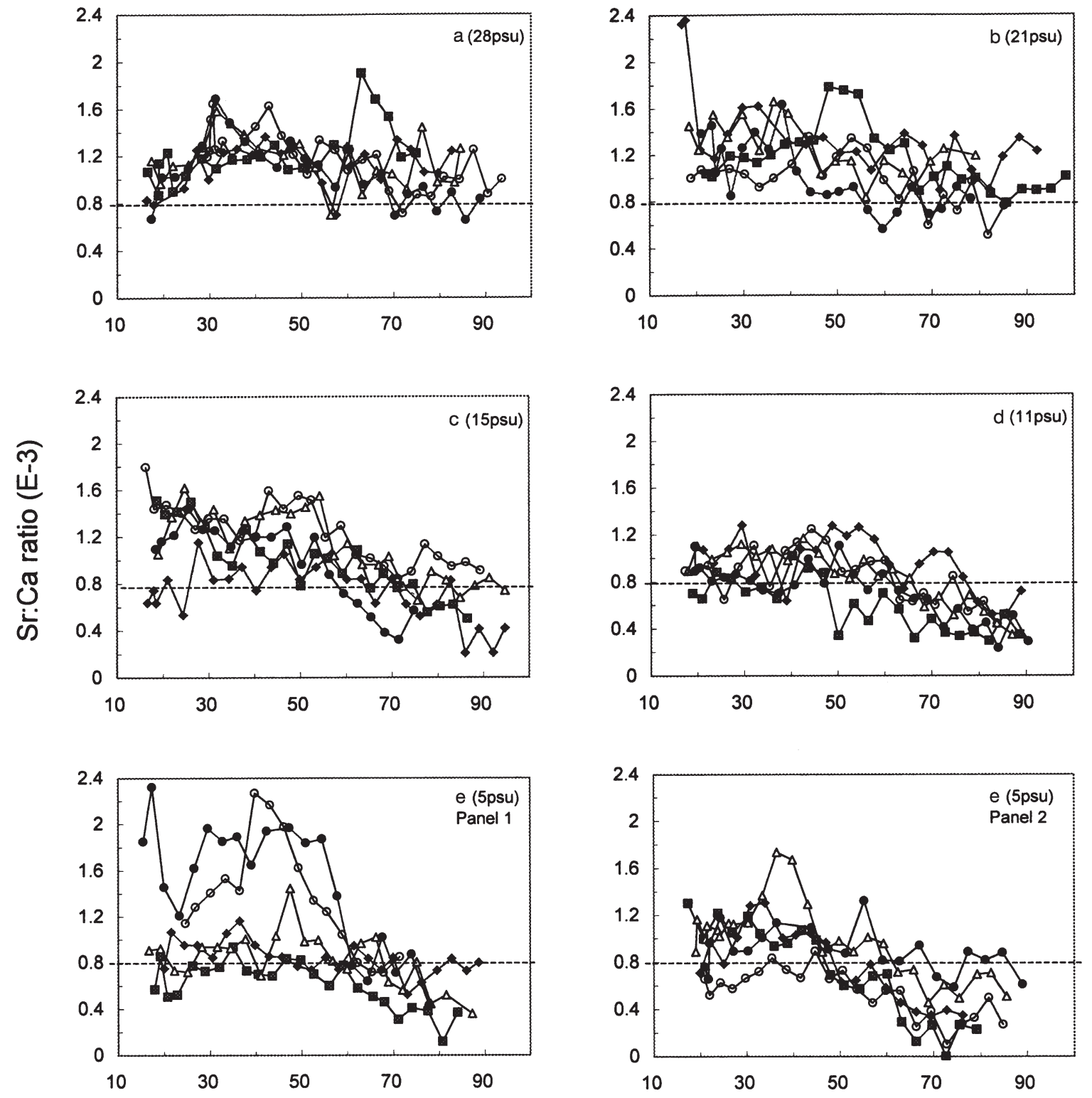

Age (day)

Fig. 4. Sr:Ca transects on otoliths of large ( $\geq 35 \mathrm{~mm}$ SL) YOY Chesapeake Bay bay anchovy collected in 1998 . Each broken line indicates a criterion level of $\mathrm{Sr}: \mathrm{Ca}=0.8 \times 10^{-3}$, which separated regions $<12$ psu from regions $\geq 18 \mathrm{psu}$ 
for a salinity effect on otolith $\mathrm{Sr}$ :Ca ratio is growing, but currently such evidence exists for only Anguilla japonicus, A. rostrata, Salvelinus alpinus, Lateolabrax japonicus, and Morone saxatilis (Secor \& Rooker 2000). Although temperature has been observed to affect otolith Sr:Ca ratio, we believe its affect is minor compared to salinity effects (see Secor et al. 1995). Bay anchovy larvae and YOY would be expected to experience similar temperature conditions during their ontogeny, despite a 2 to 3 mo long spawning season, and we failed to detect a significant effect of temperature on otolith Sr:Ca. Based upon low variance levels in the regressions of SL on age and otolith on SL, we expect that growth-rate variability was also small for our YOY sample. We believe that growth-rate variation contributed small and unbiased variance to our analysis of dispersal.

Despite the dominant role salinity played in explaining otolith $\mathrm{Sr}: \mathrm{Ca}$, considerable variability occurred in otolith Sr:Ca, particularly at 15 psu. Ambient salinity (i.e. salinity at capture) may be an imprecise measure of the salinity level that most contributed to Sr:Ca measured in the peripheral region of the otolith. Another possibility is that recent precapture dispersal from
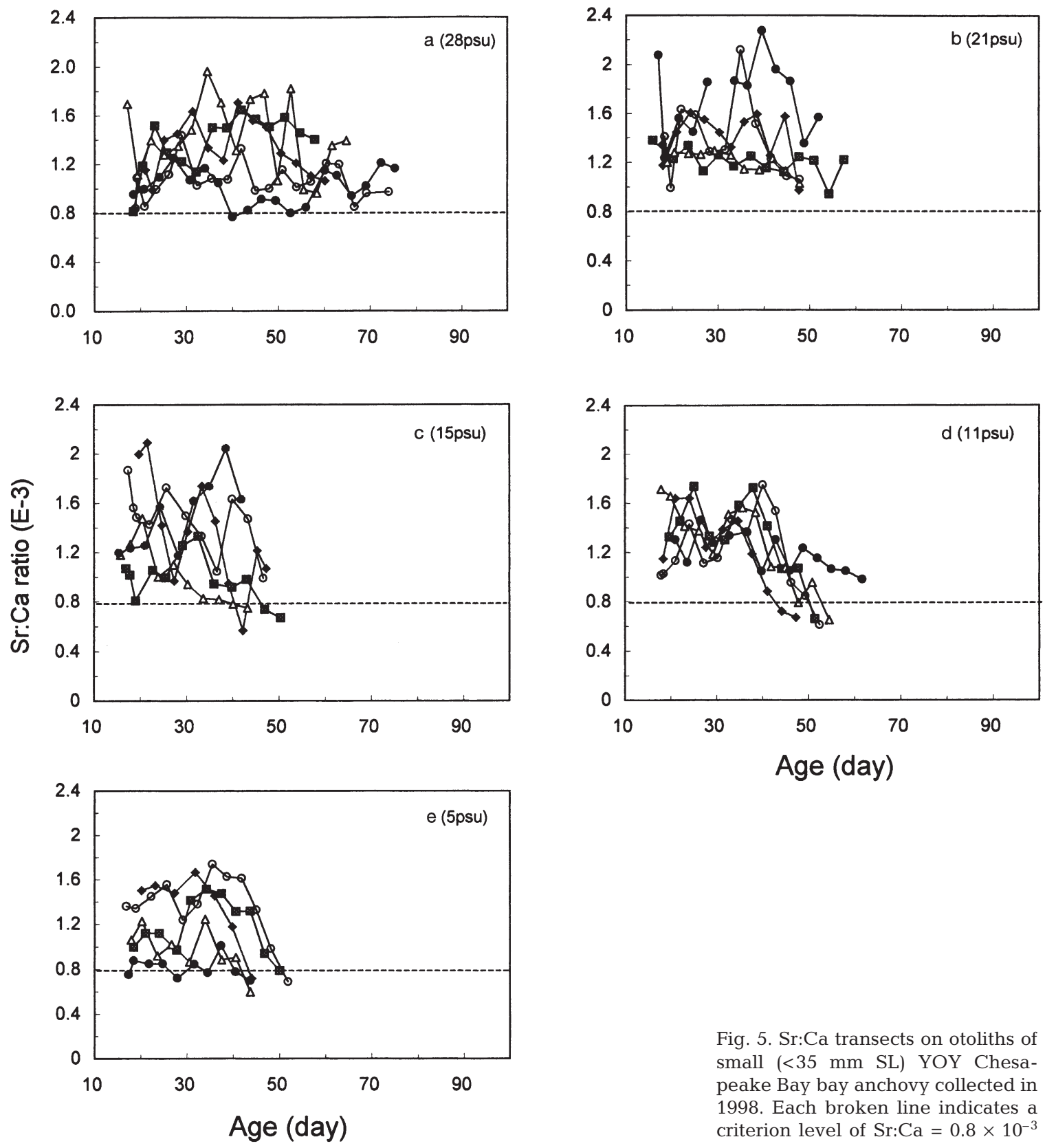

Fig. 5. Sr:Ca transects on otoliths of small $(<35 \mathrm{~mm}$ SL) YOY Chesapeake Bay bay anchovy collected in 1998. Each broken line indicates a criterion level of $\mathrm{Sr}: \mathrm{Ca}=0.8 \times 10^{-3}$ 

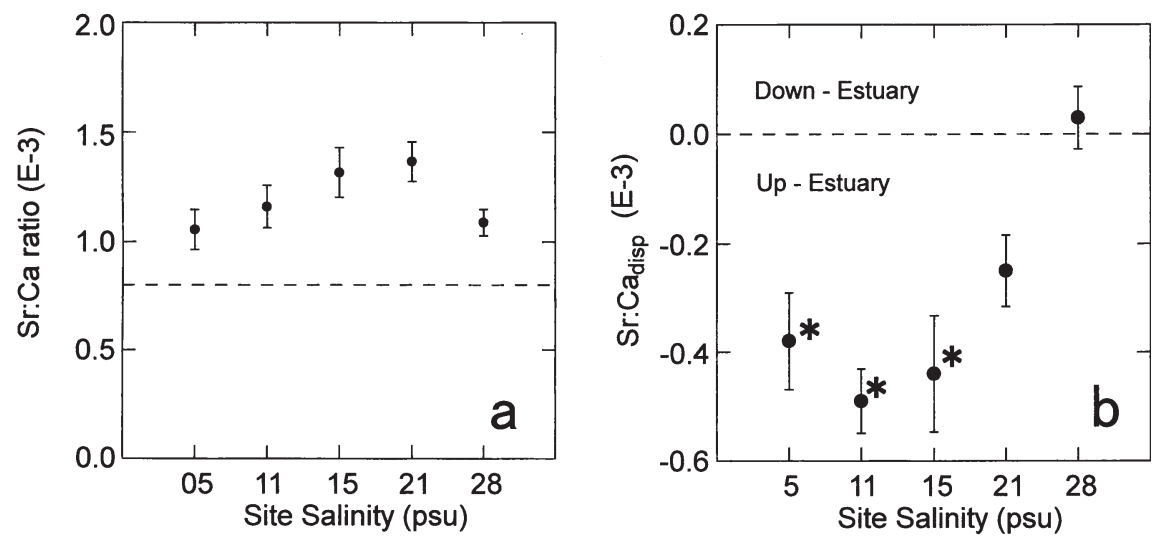

Fig. 6. (a) Mean early (ca <20 d) larval Sr:Ca levels among collection sites for YOY Chesapeake Bay bay anchovy collected in 1998. (b) Mean dispersal vectors, $\mathrm{Sr}: \mathrm{Ca}_{\text {disp }}$ among collection sites for YOY Chesapeake Bay bay anchovy collected in 1998. Vertical bars represent \pm 1 SE. ${ }^{*} p<0.05$

lower or higher bay regions contributed substantial variance to the regression. The regression was sufficiently robust to separate anchovy collected from oligohaline and polyhaline habitats and thereby supports $\mathrm{Sr}: \mathrm{Ca}$ as an index of habitat use by salinity zone and $\mathrm{Sr}: \mathrm{Ca}_{\text {disp }}$ as an overall vector of dispersal.

Estimates of over-the-ground dispersal rates (Table 3) were uncertain, given the imprecise prediction of salinity from $\mathrm{Sr}$ :Ca (inverse regression to that shown in Fig. 3). Here we must assume that estimates of salinity based upon Sr:Ca (albeit imprecise) are unbiased, i.e. we are as likely to underestimate as overestimate salinity. Residuals from the regression support this assumption, but sample-size is relatively low and probability of bias due to sampling error is significant. Extrapolation of the uncertainty (using 95\% confidence limits) in salinity prediction to calculated dispersal rates of YOY collected at 5 to 15 psu resulted in up to $14.5,6.4$, and $19.9 \%$ rate deviations at 5,11 , and $15 \mathrm{psu}$, respectively. A second important source of error is uncertainty in assigning place of origin as a consequence of anchovy inhabiting variable depths. Salinity can range as much as 15 psu with depth at a given location, but we selected the fish samples from sites exhibiting $<2$ psu difference between the surface and bottom. During June and July, mean differences between surface and bottom salinity in polyhaline regions were $9.0 \pm 3.9(\mathrm{SD})$ and $6.9 \pm 3.3 \mathrm{psu}$, respectively. MacGregor \& Houde (1996) sampled bay anchovy larvae in the mid-bay region and observed abundances of larvae 36-fold greater above than below the pycnocline, suggesting that surface salinity may be more representative of geographic location during the early larval period. However, in a baywide analysis, Rilling \& Houde (1999a) observed no difference in larval abundance above and below the pycnocline.
Because distributions of fish in the water column were combined for our samples, and the size-specific depth distribution or vertical migration pattern were unknown, we used the mean salinity between surface and bottom values in our analyses. Despite uncertainties related to prediction of place of origin, we have presented dispersal rates as coarse estimates, primarily to demonstrate how EPMA may be used to obtain dispersal rates.

Statistical tests of dispersal/migration hypotheses using EPMA data are unusual in the literature (Secor $\&$ Rooker 2000). Autocorrelation and small sample-size may be responsible for this trend, but mixed-model analysis can reduce these limitations. By specifying covariance structures among repeated measures that are more realistic, information contained in transects is utilized more efficiently. Additionally, the mixedmodel analysis does not require complete chronologies, because truncated otolith transects or those with gaps can be used in the analysis. In particular, we found the approach useful to detect differences in agespecific dispersal patterns.

Individuals collected at 5 to 11 psu initiated detectable up-estuary dispersals between the ages of 45 and $59 \mathrm{~d}$ at ca $\geq 25 \mathrm{~mm}$ SL. This timing coincides with the larval transformation and early juvenile period, near the time of metamorphosis (Houde \& Zastrow 1991). In coastal demersal species like the Japanese flounder Paralicthyth olivaceus, plaice Pleuronectes platessa, English sole Parophrys vetulus, and red sea bream Pagrus major, habitat shifts which correspond to juvenile metamorphosis are well documented (Minami 1982, Rijnsdorp et al. 1985, Tanaka 1985, Boehlert \& Mundy 1987). In these species, shifts in habitat at metamorphosis are conspicuous due to marked changes in biological and habitat attributes associated with the niche shift. Subtler ontogenetic habitat shifts by estuarine fishes may occur across salinity regimes, but these have been difficult to document and investigate using traditional sampling and tagging approaches. This is especially true for pelagic species such as bay anchovy that are ubiquitous, abundant, and do not exhibit discrete modes of habitat use related to different life-history stages.

While transect analysis of otolith Sr:Ca demonstrated up-estuary dispersal by bay anchovy, it remains unknown how, or if, this behavior is particularly beneficial to growth and survival by migrants. Dovel (1971) postulated that the zone of oligohaline water provides improved nursery conditions for fish larvae and juve- 
niles. The maximum turbidity front (Schubel 1968) occurs within the oligohaline zone and may concentrate zooplankton prey (Rilling \& Houde 1999a). In addition, the scyphomedusan Chrysaora quinquecirrha, an important predator on anchovy larvae (Purcell et al. 1994), does not survive in the freshwater oligohaline regions of Chesapeake Bay (Cargo \& Schultz, 1966, Wright \& Purcell 1997). A second abundant predator of fish larvae, the lobate ctenophore Mnemiopsis leidyi, can occur at high densities in oligohaline regions of the Chesapeake Bay. Although Rilling \& Houde (1999a) observed high densities of $M$. leidyi in the upper Chesapeake Bay ( $<8$ psu) in July 1993, they also observed that those larvae collected at oligohaline sites experienced lower mortality rates and higher growth rates than at mesohaline or polyhaline sites (Rilling \& Houde 1999b). While attributes in predation fields and vital rates were determined for only early stage larvae in the 1993 study, they may support a nursery role in the upper bay for YOY as well. Having now demonstrated that up-estuary dispersal occurs in bay anchovy, the second part of the critical-zone hypothesis-i.e. what are the ecological consequences of up-estuary dispersal - remains an open question deerving further investigation. In the future, the critical zone hypothesis - i.e. higher rates of recruitment occur from individuals that utilized oligohaline regions as nursery habitat - could be tested by hind-casting YOY habitat use from adult otoliths.

Based upon the mean size at which oligohaline-destined YOY anchovy began to disperse ( $\mathrm{SL}=35 \mathrm{~mm}$ ), maximum dispersal rate was ca 2 body lengths s ${ }^{-1}$. This is a conservative estimate of migration rate, since we have assumed linear dispersal over the bottom, regardless of tides and residual currents. Blaxter \& Hunter (1982) reported that cruising speeds in juvenile clupeoid fishes ranged from 1 to 5 body lengths $\mathrm{s}^{-1}$. YOY (size range 20 to $100 \mathrm{~mm} \mathrm{SL}$ ) of other species apparently are capable of sustained swimming at 5 to 13 body lengths $\mathrm{s}^{-1}$ (Goolish 1991). Taking into consideration that we were unable to statistically distinguish polyhaline points of origin from mesohaline ones (15 psu, Fig. 3), it is possible that larvae originated from mid-bay prior to ingress into up-bay regions $(<15 \mathrm{psu})$. If this is true, the dispersal rates would be about half of our original estimate. Also, egg production occurred throughout the lower two-thirds of Chesapeake Bay in 1998 (E. Houde pers. obs). Therefore, while we have shown strong evidence for directed migrations, we have reason to believe that dispersal rates could be either negatively biased due to assumed linear dispersal or positively biased due to imprecision in the otolith Sr:Ca method.

Directed migrations may be cued by biotic gradients in predators, and prey may be related to salinity gradi- ents, and could provide cues for oriented swimming. Juveniles also could use selective tidal stream transport to accomplish up-estuary dispersal (Weinstein et al. 1980, Tanaka 1985). Alternatively, residual up-estuary currents near the bottom occur in Chesapeake Bay and are particularly strong in the deep axial channel (Goodrich \& Blumberg 1991). These currents may facilitate up-estuary dispersal of fish.

However up-estuary dispersal is accomplished, an important alternative concept to directed migration is one of transport to regions throughout the Chesapeake Bay (panmixia), regardless of potential cues or preferred habitats. In laboratory and field studies, Luo (1993) observed that juvenile and adult bay anchovy schooled during the day, but that schools broke up at night. While schooling, anchovy retained their position and swam against imposed currents. But when dispersed at night, individuals were advected by prevailing currents. This pattern of nocturnal transport potentially could lead to rapid dispersal throughout the estuary. Otolith $\mathrm{Sr}$ :Ca analysis did not support this pattern of random dispersal. If up-estuary dispersals occurred due to nocturnal tides, we would not expect to observe the high degree of autocorrelation in $\mathrm{Sr}: \mathrm{Ca}$ among adjacent age-classes (Table 2). The otolith data also show a pattern of oriented migration, without strong evidence of periods of down-estuary dispersal intermingled with periods of up-estuary dispersal, a pattern which would be predicted based upon nocturnal tidal transport.

Year-to-year variability in distributions of recruits is evident and annual variability in recruitment levels could be related to up-bay dispersal rates and patterns. The EPMA approach, combined with analysis of stagespecific abundances, holds promise in explaining how bay anchovy and other species disperse in estuaries during early life.

Acknowledgements. Research was conducted as part of a visiting program between R.K. and D.H.S. funded by The Science and Technology Agency, Japan. Further support for field and laboratory work came from the National Science Foundation (Grant no. OCE-98-12069 to D.H.S. and OCE-9521512 to E.D.H.), and the NSF TIES Grant (DEB 94-12113 to E.D.H.). We are grateful to T. Gunderson, S. Jung, A. Madden, S. Larsen, S. Leach, E. North, D. O'Brien, V. Caceres, E. Niklitschek, S. McGuire, and S. Ju, who assisted with field surveys and laboratory analyses. We thank Dr Oozeki for his critical reviews of this manuscript.

\section{LITERATURE CITED}

Blaxter JH, Hunter JR (1982) The biology of the clupeoid fishes. In: Blaxter JH, Russell FS, Yonge M (eds) Advances in marine biology, Vol 20. Academic Press, London, p 3-223

Boehlert GW, Mundy BC (1987) Recruitment dynamics of metamorphosing English sole, Parophrys vetulus, to Yaquina Bay, Oregon. Estuar Coast Shelf Sci 25:261-281 
Campana SE (1999) Chemistry and composition of fish otolith: pathways, mechanisms and applications. Mar Ecol Prog Ser 188:263-297

Cargo DG, Schultz LP (1966) Notes on the biology of the sea nettle, Chrysaora quinquecirrha, in Chesapeake Bay. Chesapeake Sci 7:95-100

Chambers RC, Miller TJ (1995) Evaluating fish growth by means of otolith increment analysis: special properties of individual-level longitudinal data. In: Secor DH, Dean JM, Campana SE (eds) Recent developments in fish otolith research. University of South Carolina Press, Columbia, p 155-175

Dovel WL (1971) Fish eggs and larvae of the Upper Chesapeake Bay. National Research Institute, University of Maryland, Spec Rep No. 4, College Park

Fives JM, Warlen SM, Hoss DE (1986) Aging and growth of larval bay anchovy, Anchoa mitchilli, from the Newport River Estuary, North Carolina. Estuaries 9:362-367

Fowler AJ, Campana SE, Jones CM, Thorrold SR (1995) Experimental assessment of the effect of temperature and salinity on elemental composition of otoliths using laser ablation ICPMS. Can J Fish Aquat Sci 52:1431-1441

Goodrich DM, Blumberg AF (1991) The fortnighly mean circulation of Chesapeake Bay. Estuar Coast Shelf Sci 32: 451-462

Goolish EM (1991) Aerobic and anaerobic scaling in fish. Biol Rev 66:33-56

Gunn JS, Harrowfield IR, Proctor CH, Thresher RE (1992) Electron probe microanalysis of fish otoliths - evaluation of techniques for studying age and stock discrimination. J Exp Mar Biol Ecol 158:1-36

Hartman KJ, Brandt SB (1995) Trophic resource partitioning, diets, and growth of sympatric estuarine predators. Trans Am Fish Soc 124:520-537

Hildebrand SF, Schroeder WC (1928) Fishes of Chesapeake Bay. Bull US Bur Fish 43:108-110

Houde ED, Zastrow CE (1991) Bay anchovy. In: Funderburk SL, Jordan SJ, Mihursky JA, Riley D (eds) Habitat requirements for Chesapeake Bay living resources. Chesapeake Bay Program, Annapolis, Chap 8, p 8-14

Leak JC, Houde ED (1987) Cohort growth and survival of bay anchovy Anchoa mitchilli larvae in Biscayne Bay, Florida. Mar Ecol Prog Ser 37:109-122

Littell RC, Milliken GA, Stroup WW, Wolfinger RD (1996) SAS system for mixed models. SAS Institute Inc, Cary, NC

Loos JL, Perry ES (1991) Larval migration and mortality rates of bay anchovy in the Patuxent River. Proc 13th Larval Fish Conf 65-76

Luo J (1993) Tidal transport of the bay anchovy, Anchoa mitchilli, in darkness. J Fish Biol 42:531-539

MacGregor JM, Houde ED (1996) Onshore-offshore pattern and variability in distribution and abundance of bay anchovy Anchoa mitchilli eggs and larvae in Chesapeake Bay. Mar Ecol Prog Ser 138:15-25

Minami T (1982) The early life history of a flounder Par-

Editorial responsibility: Kenneth Tenore (Contributing Editor), Solomons, Maryland, USA alichthys olivaceus. Bull Jpn Soc Sci Fish 48:1581-1588 (in Japanese)

Purcell JE, Nemazie DA, Dorsey SE, Houde ED, Gamble JC (1994) Predation mortality of bay anchovy Anchoa mitchilli eggs and larvae due to scyphomedusae and ctenophores in Chesapeake Bay. Mar Ecol Prog Ser 114: 47-58

Rijnsdorp AD, van Stralen M, van der Veer HW (1985) Selective tidal transport of North Sea plaice larvae Pleuronectes platessa in coastal nursery areas. Trans Am Fish Soc 114: 461-470

Rilling GC, Houde ED (1999a) Regional and temporal variability in distribution and abundance of bay anchovy (Anchoa mitchilli) eggs, larvae and adult biomass in the Chesapeake Bay. Estuaries 22:1096-1109

Rilling GC, Houde ED (1999b) Regional and temporal variability in growth and mortality of bay anchovy (Anchoa mitchilli) eggs, larvae and adult biomass in the Chesapeake Bay. Fish Bull US 97:555-569

Schubel JR (1968) Turbidity maximum of the northern Chesapeake Bay. Science 161:1013-1015

Secor DH (1992) Application of otolith microchemistry analysis to investigate anadromy in Chesapeake Bay striped bass Morone saxatilis. Fish Bull US 90:798-806

Secor DH, Piccoli PM (1996) Age- and sex-dependent migrations of striped bass in the Hudson River as determined by chemical microanalysis of otoliths. Estuaries 19:778-793

Secor DH, Rooker JR (2000) Is otolith strontium a useful scalar of life cycles in estuarine fishes? Fish Res 46:359-371

Secor DH, Dean JM, Laban EH (1992) Otolith removal and preparation for microstructural examination. In: Stevenson DK, Campana SE (eds) Otolith microstructure examination and analysis. Can Spec Publ Fish Aquat Sci 117: $19-57$

Secor DH, Henderson-Arzapalo A, Piccoli PM (1995) Can otolith microchemistry chart patterns of migration and habitat utilization in anadromous fishes? J Exp Mar Biol Ecol 192:15-33

Tanaka M (1985) Factors affecting the inshore migration of pelagic larval and demersal juvenile red sea bream Pagrus major to a nursery ground. Trans Am Fish Soc 114: 471-477

Thresher RE (1999) Elemental composition of otoliths as a stock delineator in fishes. Fish Res 43:165-204

Weinstein MP, Weiss SL, Hodson RG, Gerry LR (1980) Retension of three taxa of postlarval fishes in an intensively flushed tidal estuary, Cape Fear River, North Carolina. Fish Bull US 78:419-436

Wright DA, Purcell JE (1997) Effect of salinity on ionic shifts in mesohaline scyphomedusae, Chrysaora quinquecirrha. Biol Bull 192:332-339

Zastrow CE, Houde ED, Morin LG (1991) Spawning, fecundity, hatch-date frequency and young-of-the-year growth of bay anchovy Anchoa mitchilli in mid-Chesapeake Bay. Mar Ecol Prog Ser 73:161-171

Submitted: January 5, 2000; Accepted: July 13, 2000

Proofs received from author(s): November 6, 2000 